\title{
Plasma Cholinesterase Activity in Wild Birds from Undisturbed Woodlands in the Central Monte Desert
}

\author{
Arnoldo Ángel Martín Quero, ${ }^{a, b}$ Agustín Zarco, ${ }^{a, b, c}$ Florencia Belén Landa, ${ }^{b}$ and Nora Bibiana María Gorla ${ }^{a, b, *}$ \\ ${ }^{a}$ Consejo Nacional de Investigaciones Científicas y Técnicas, Buenos Aires, Argentina \\ bLaboratorio de Genética, Ambiente y Reproducción, Universidad Juan Agustín Maza, Guaymallén, Mendoza, Argentina \\ 'Laboratorio de Biología de Aves, Grupo de Ecología del Comportamiento Animal, Instituto Argentino de Investigaciones en Zonas Aridas, Consejo Nacional de \\ Investigaciones Científicas y Técnicas-Universidad Nacional de Cuyo, Mendoza, Argentina
}

Abstract: Plasma cholinesterase activity is a biomarker sensitive to the effect of organophosphate and carbamate pesticides, and its enzymatic levels have been previously unknown for most of the wild birds analyzed in the present study. Our objectives were to establish plasma acetylcholinesterase levels in songbirds of 2 undisturbed sites in the central Monte Desert (Argentina). We also examined the influence on cholinesterase activity of age, sex, body condition, feeding and migratory habits, and species. One hundred and sixty-five wild birds belonging to 26 species were studied. The values obtained for acetylcholinesterase activity provide a good estimate of the normal values in free-living individuals of the species Zonotrichia capensis, Molothrus bonariensis, Passer domesticus, Diuca diuca, Poospiza ornata, Saltator aurantiirostris, Gryseotyrannus aurantioatrocristatus, and Columbina picui, with interspecies differences. The median enzymatic levels \pm standard error of the mean ranged from $546.31 \pm 17.97 \mu \mathrm{mol} \mathrm{min}^{-1} \mathrm{~L}^{-1}$ in $P$. domesticus to $3439.90 \pm 173.92 \mu \mathrm{mol} \mathrm{min}{ }^{-1} \mathrm{~L}^{-1}$ in Tyrannus melancholicus. No significant differences were detected between different sexes or ages. Birds that migrate (which are also insectivores) showed higher levels of cholinesterase than residents (mainly granivores). It is recommended that in cases of bird poisoning, plasma cholinesterase activity can be used as a diagnostic tool only if pre-exposure levels obtained in the same species are available, and ideally evaluated in individuals from the same biogeographical region. Environ Toxicol Chem 2019:1-9. @ 2019 SETAC

Keywords: Plasmatic cholinesterase; Wild birds; Songbirds; Variability factors

\section{INTRODUCTION}

Birds are one of the groups most sensitive to the toxic effects produced by organophosphate and carbamate anticholinesterase pesticides (Mitra et al. 2011; Ruvalcaba-Ortega et al. 2017). The median lethal doses of these compounds are between 10 to 20 times lower in birds than in mammals (Kaneko et al. 2008). The enzyme cholinesterase (ChE) catalyzes the hydrolysis of the neurotransmitter acetylcholine by inhibiting esterases in the central and peripheral nervous systems, ending the nerve impulse (Nunes 2011). Intoxication events with pesticides in humans and wild animals occur frequently (Guitart et al. 2010; Sánchez-Barbudo et al. 2012). In our region of Argentina, organophosphates and carbamates constitute $49 \%$ of the total cases of poisoning in people living in agricultural areas (Toxicological Information Center 2018), where aldicarb and

This article includes online-only Supplemental Data.

* Address correspondence noragorla@gmail.com

Published online 7 May 2019 in Wiley Online Library

(wileyonlinelibrary.com).

DOI: 10.1002/etc.4458 carbofuran have been the causative agents of recent intoxications in canines and pigeons (Ferré et al. 2015; Saldeña et al. 2017). These latter pesticides are easily available, and the legal and illegal use of organophosphates and carbamates represents a serious threat to birds (Oropesa et al. 2013). The inhibition of ChE in birds and mammals induces acute toxicity, with symptoms that include lack of coordination, weakness, ataxia, muscle tremor, diarrhea, seizures, breathing difficulties (respiratory distress), bradycardia, paralysis, and fatal respiratory failure (Shimshoni et al. 2012). For the causal diagnosis of birds with signs of anti-ChE intoxication after accidental or intentional events, we need to obtain ChE activity levels in birds that reside in protected natural sites, apparently without exposure to pesticides. Inhibition of cerebral acetylcholinesterase (AChE) has been used as a biomarker of neurotoxicity from organophosphates and carbamates, with a $20 \%$ decrease in AChE being diagnostic of exposure to these groups of pesticides (Mineau 2002). To avoid animal euthanasia, plasma ChE activity is measured because $\mathrm{ChE}$ is also a biochemical biomarker of exposure to organophosphates and carbamates (Strum et al. 2010; Oropesa et al. 2013). Plasma AChE activity is also used as a biomarker for 
environmental analysis (Nunes 2011), because it is a useful tool to evaluate the possibility of environmental pollution in birds from certain pesticides (Stuber et al. 2018). Environmental factors that can produce variations in ChE activity have been reported (Tecles and Cerón 2001), and ChE activity in birds is subject to interspecific and intraspecific species variations (Roy 2005; Cobos et al. 2010). Therefore, it is important to determine the ChE activity reference intervals in each species (Horowitz et al. 2016).

The Monte Desert occupies an extensive area in the west of Argentina. Even though it is an arid region, it has great ornithological diversity (Cueto et al. 2008) and consists of protected areas with no agricultural activity and no pesticides as well as areas where fruit and vegetables are cultivated and antiChE insecticides are widely used (Ferré et al. 2018). Plasma AChE activity levels have not previously been determined in bird species representative of the Monte Desert. The objective of the present study was to analyze the plasma AChE activity of several wild bird species living in undisturbed natural sites of the Monte Desert phytogeographic region. When possible, we also explored whether a relationship exists between AChE activity levels and factors such as species category, sex, age, and feeding and migratory habits.

\section{MATERIALS AND METHODS}

The present study was carried out in 2 protected sites of the central Monte Desert: The Telteca Forest Reserve and the Ñacuñán Biosphere Reserve, located 233 km apart from each other (Figure 1). These sites represent areas in which no agricultural activity is carried out and both provide a breeding habitat and/or migratory scale for more than 100 species of wild birds throughout the year (Cueto et al. 2008). The climate is arid, with high evaporation rates and wide variations in temperature, from $16^{\circ} \mathrm{C}$ in winter up to 40 to $42{ }^{\circ} \mathrm{C}$ in summer; rainfall ranges from 200 to $400 \mathrm{~mm} / \mathrm{yr}$, concentrated mainly in the summer (Abraham et al. 2009). Both sites are shrub steppes, with mostly Larrea spp. (Zygophyllaceae) and Prosopis flexuosa, which forms open forests (Villagra et al. 2009). Both have been identified as important bird and biodiversity areas (BirdLife International 2018).

\section{Sampling of birds}

Birds were captured using mist nets $(12 \mathrm{~m} \times 3 \mathrm{~m}, 34 \mathrm{~mm})$. Nets were deployed from 6 AM to 8 PM and were checked every 20 min. Birds were systematically removed from the nets according to Ralph et al. (1996). The birds were classified following Remsen et al. (2015). We performed an external examination to estimate the visible fat depots in the interclavicular region (furcular fat) using a relative scale from 0 to 3 (Ralph et al. 1996). The birds showed no signs of intoxication. Sex was determined in the species with external sexual dimorphism, and age (according to the presence of labial commissure) was noted as adult or juvenile.
The blood samples were obtained from the brachial vein, collected in heparinized capillary tubes, and kept at $4{ }^{\circ} \mathrm{C}$ until processing. Plasma was obtained by centrifugation at 10000 rpm for $5 \mathrm{~min}$. Samples were refrigerated and transferred to the Laboratory of Genetics, Environment, and Reproduction at the University Juan Agustín Maza (Guaymallén, Mendoza, Argentina), where they were kept at $-80^{\circ} \mathrm{C}$ until analysis. Sampling was conducted between October and December 2017, and the birds were released in the original place of their capture. The fieldwork protocol was evaluated and approved by the Institutional Committee for the Care and Use of Laboratory Animals, Research and Teaching (CICUALID-UMaza; Protocol 119).

\section{Determination of AChE activity: Validation of the method}

The analysis was carried out according to the method of Ellman et al. (1961) as modified by Trudeau and Sans Cartier (2000). 5,5-Dithiobis-2-nitrobenzoic acid $(0.26 \mathrm{mmol} / \mathrm{L}$; Sigma-Aldrich) in phosphate buffered saline solution at $\mathrm{pH} 7.5$ was used as the chromogen, and a solution of acetyl thiocholine iodide (CAS No. 1866-15-5; Sigma-Aldrich) was used as the substrate (0.156 M). The determination was carried out at $25^{\circ} \mathrm{C}$ at $405 \mathrm{~nm}$ in a spectrophotometer (Varian Cary Ultraviolet-visible; Agilent) at 0, 30, 60, and $90 \mathrm{~s}$. For all samples, a single measurement was taken, due to the low volume of blood extracted from each specimen, which constituted less than 1\% of body weight (Fair and Jones 2010).

The linearity of the enzymatic activity was tested with a plasma sample from Molothrus bonariensis, the passeriform with the highest volume of blood extracted, enough to perform the linearity curve in triplicate. The following concentrations were used: undiluted plasma (100\%) and increasing dilutions with physiological solution of $50,25,12.50$, and $6.25 \%$ plasma. The coefficient of variation of each triplicate set was obtained. Determinations in all birds were made with the same batch of chromogen and substrate.

\section{Statistical analysis}

The linearity of the determination of AChE activity was evaluated by Pearson's linear regression test between the different dilutions of the blood plasma and the enzymatic activity. The AChE activity levels are presented as mean \pm standard error of the mean (SEM), with minimum and maximum values by species and by site under study. As a pre-established criterion, the possible effects of different factors on the enzymatic levels were analyzed only among those species in which 5 or more individuals were available. Using the Spearman test, we analyzed whether there was a correlation among the variables sex, age, body weight, fat interclavicular depots, residence status (resident and migrant), and food guilds (omnivores, granivores, insectivores) of individuals with plasma AChE levels. To evaluate variation effects factors, data were log normalized and a mixed generalized linear model was used, using the $t$ tests of Satterthwaite's method with the Imer 1.0 package 


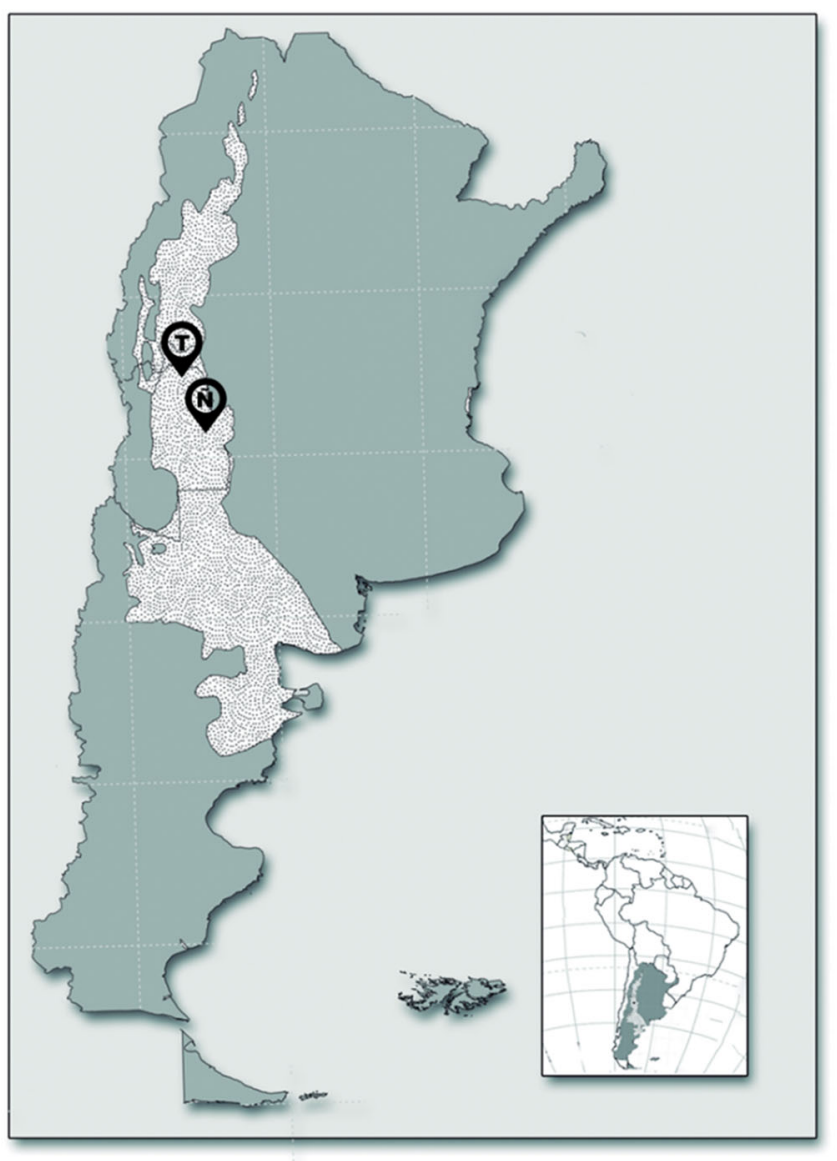

FIGURE 1: Map showing the biogeographic province of the central Monte Desert (shaded) in terms of Argentina and South America. $\mathrm{T}=$ Telteca Natural Reserve $\left(32^{\circ} 23^{\prime} 27^{\prime \prime} \mathrm{S}, 68^{\circ} 01^{\prime} 30^{\prime \prime} \mathrm{W}, 540\right.$ meters above sea level [masl]); $\tilde{N}=\tilde{N}$ acuñán Biosphere Reserve $\left(34^{\circ} 03^{\prime} 0^{\prime \prime} \mathrm{S}, 67^{\circ} 58^{\prime} 0^{\prime}\right.$ 'W, 583 masl).

(Kuznetsova et al. 2017) in R Ver 3.3.2, 2016. The AChE activity was used as the dependent variable and the site as a random variable. InfoStat software Ver 2016 was used to design the graphics.

\section{RESULTS}

In the AChE activity linearity study, the range of dilutions tested showed a highly significant relationship between plasma dilutions and enzymatic activity: $r^{2}=0.98, p \leq 0.001$ (Figure 2). The average enzymatic activity (mean \pm SEM) of an initial undiluted plasma sample was $1832.15 \pm 41.15 \mu \mathrm{mol}$ $\mathrm{min}^{-1} \mathrm{~L}^{-1}$ (coefficient of variation $3.96 \%$ ); and the same activity for the diluted samples was as follows: 1:2 dilution, $722.67 \pm 1.19 \mu \mathrm{mol} \mathrm{min}{ }^{-1} \mathrm{~L}^{-1}$ (coefficient of variation $0.29 \%$ ); $1: 4$ dilution, $351.42 \pm 0.59 \mu \mathrm{mol} \mathrm{min}{ }^{-1} \mathrm{~L}^{-1}(0.29 \%) ; 1: 8$ dilution, $212.20 \pm 1.73 \mu \mathrm{mol} \mathrm{min}^{-1} \mathrm{~L}^{-1}$ (coefficient of variation 1.41); and 1:16 dilution, $130.95 \pm 1.24 \mu \mathrm{mol} \mathrm{min}^{-1} \mathrm{~L}^{-1}$ (coefficient of variation 1.64\%).

A total of 165 wild birds belonging to 26 different species were captured from the 2 sites (Table 1). The birds appeared to be healthy; body weight and fat depots are shown in the
Supplemental Data. The minimum and maximum AChE values generally varied among individuals of the same species by approximately 2.5-fold, and extended from 1.2-fold in Patagioenas maculosa to 4.7-fold in Poospiza ornata. Six species were represented in both reserves, with similar intraspecific AChE activity. The species and their average levels of AChE were as follows: Zonotrichia capensis $2086.99 \pm 89.47(n=35)$; M. bonariensis $1691.31 \pm 122.56(n=20)$; Passer domesticus $546.31 \pm 17.97(n=10)$; Saltator aurantiirostris $1724.05 \pm$ 142.38 ( $n=11)$; Turdus amaurochalinus $1683.24 \pm 627.51$ $(n=2)$; and Columbina picui $943.65 \pm 82.91(n=13)$.

The range of AChE activity between species extended from the minimum mean for $P$. domesticus, to the maximum mean (6.2-fold) for Tyrannus melancholicus. A model for the possible factors of variation was created for 8 species according to the pre-established criteria. The variability among all species is shown in Table 2.

We were able to carry out gender analysis in the 3 species that presented clear external sexual dimorphism, M. bonaerensis, $P$. ornata, and $S$. aurantirrostris. The AChE activity between females and males in those 3 species was not significantly different ( $p=0.1785, d f=37.05, t=1.371$; Figure 3A). Analysis between ages could only be performed in $P$. domesticus, and the plasma activity between adults and juveniles was also not significantly different ( $p=0.5879, d f=22.02, t=0.55$; Figure $3 \mathrm{~B}$ ). We were able to evaluate the correlation between AChE levels and body weight by species in 8 species, and a negative correlation was observed only in Z. capensis $(p=0.01, r=-0.43$; Supplemental Data). No association was found between fat interclavicular depots and levels of plasma AChE activity for any of the species analyzed (Supplemental Data). In the residence status analysis, it was found that of the total birds captured, $62.5 \%$ were resident species and $37.5 \%$ were migratory species. Between migrants and residents, the plasma AChE values were significantly higher for migrants $(p=0.0007, d f=127.00, t=3.49$; Figure $3 C$ ). The plasma AChE activity was different between granivores $(p=0.0045, d f=1.00, T=142.142)$ and insectivores $(p=0.0005, d f=113.64, T=3.602$, Figure $3 D)$ compared with omnivores.

\section{DISCUSSION}

When it is possible to collect only small volumes of blood samples (in studies such as ours that sample passerines), one must choose a single AChE endpoint, which also allows comparison across species. We selected the Ellman method, with acetylthiocholine as the substrate (González-Escalante et al. 2013; Stuber et al. 2018), due to the high specificity of the AChE (Miao et al. 2010) and the availability of data in the literature to make comparisons between species and sampling sites. On the other hand, characterizing and selecting the most appropriate substrate in each species for acetyl, butyryl, or propionyl ChEs is the procedure indicated when the first step in biomonitoring is to identify a focal species (European Food Safety Authority 2009). We also note that interlaboratory variability in the determination of AChE has been reported, 
even when the same basic analytical method is used (Tecles and Cerón 2001). Given this reality, we believe that for biomonitoring situations, each laboratory should create the data for its own reference control groups.

In the present study we observed an overall variability in the range of AChE activity between species, which was higher than the interindividual variations within each species. The high variation in AChE activity could potentially be due to intrinsic characteristics of the species. In terms of other taxonomic classes (mammals, for example), AChE activity is also different between species (Kaneko 2008), with phylogeny being one of the possible explanatory factors (Roy 2005); other authors have speculated that the genotype of birds is more influential than the environment (Norte et al. 2009). In the present study, the maximum AChE activity was detected in T. melancholicus, exceeding by 9 times the minimum value detected in $P$. domesticus, which exhibited the lowest value $\left(0.546 \pm 0.017 \mu \mathrm{mol}^{-1} \mathrm{~min}^{-1} \mathrm{~L}, \mathrm{n}=10\right)$. Passer domesticus is a species that has a close relationship with humans and is an obligate commensal of sedentary humans (Anderson 2006). In other bird species, it has been observed that groups living with humans had lower ChE levels than groups without daily contact (Zwarg et al. 2012). On the other hand, in the studies conducted by González-Escalante et al. (2013), $P$. domesticus seemed to be the species most sensitive to the inhibition of ChE activity among the species studied. The average ChE activity level we obtained for $P$. domesticus inhabiting the Monte Desert was lower than that reported in Mexico for both nonagricultural-area individuals $\left(1379 \pm 0.338 \mu \mathrm{mol}^{-1} \mathrm{~min}^{-1} \mathrm{~L} ; n=\right.$ 7) and agricultural-area individuals $\left(0.998 \pm 0.289 \mu \mathrm{mol}^{-1} \mathrm{~min}^{-1} \mathrm{~L}\right.$; $n=7)$.

We found no differences between males and females, or between juveniles and adults (Figure $3 \mathrm{~A}$ and $\mathrm{B}$ ), in the species we were able to evaluate. Sex, age, and physiological and reproductive status have been suggested as causes of biological variability in human, rodent, and domestic animal plasma ChE activity (Tecles and Cerón 2001; Vaughan-Higgins et al. 2016). In birds, it has been reported that different sexes and ages differ in their enzymatic biochemistry and physiological activity (Maul and Farris 2004; Roy 2005; Norte et al. 2009), but this issue is not well defined; other studies like ours found no differences (Zwarg et al. 2012). Because other authors have indicated that juvenile birds may be more sensitive than adults to compounds that inhibit ChEs (Kaneko et al. 2008), it is important to clarify this issue.

It has been reported that migrating birds may be particularly susceptible to exposure and negative effects of neurotoxic insecticides, because they may stray into pesticide-treated crops during migration (Smith and McWilliams 2014). However, in our study, the migrant species showed higher mean AChE activity values than the resident species, which hypothetically are less likely to move from large reserves to agricultural sites. For at least $10 \mathrm{~km}$ around the sampling site, there is no agriculture land or apparent application of pesticides. We believe that the possible exposure to agricultural pesticides in resident birds can only be linked to displacement distances: large distances traveled would increase the chances of entering agricultural fields.

Most of the individuals we captured were granivores and insectivores, in line with the main trophic groups reported for these sites (Cueto et al. 2008). The granivore species had the lowest enzymatic activity means, and the insectivore species had the highest. Globally, it has been found that granivore birds can be seriously impacted by several insecticides (BirdLife International 2018). Consideration of the food consumed by the species could indicate the potential risk agents for birds. In agricultural areas, the possibilities of intoxication in birds can be shown by the type and rate of food intake (European Food

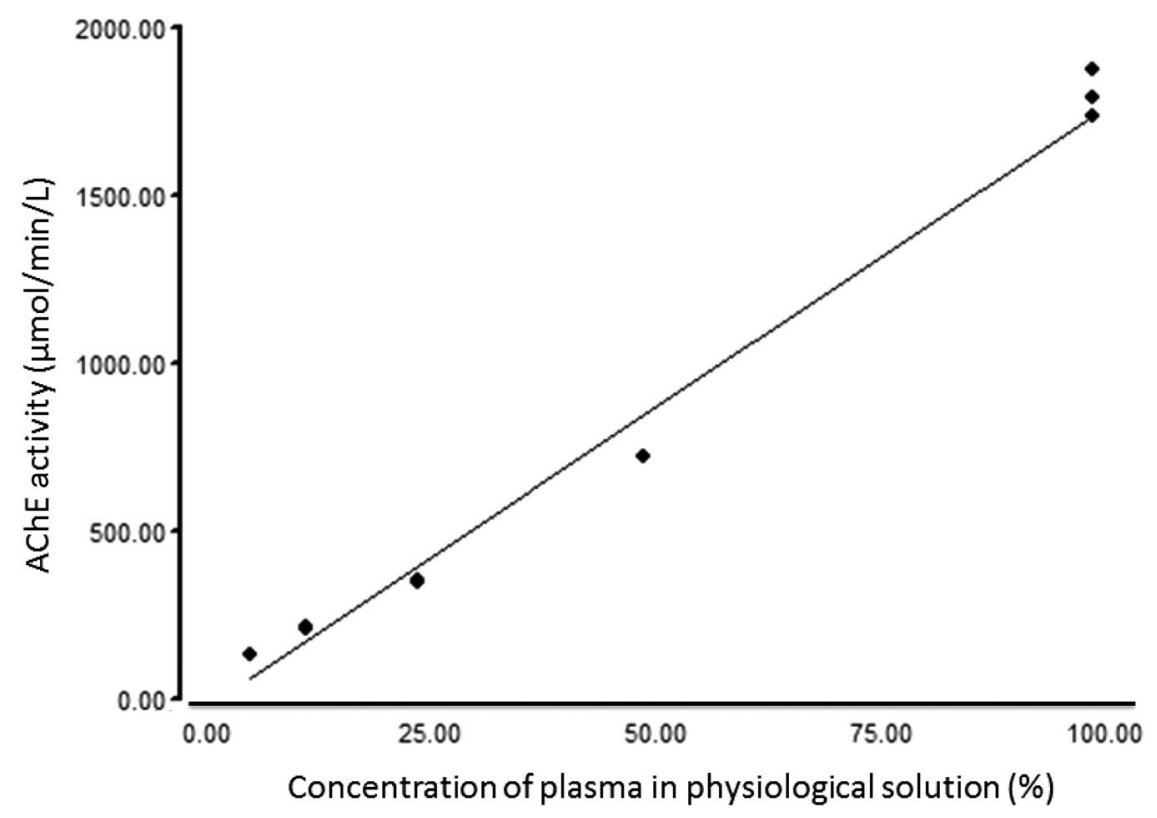

FIGURE 2: Linearity of acetylcholinesterase activity in a wild passerine plasma $\left(r^{2}=0.98, p \leq 0.001\right)$. AChE $=$ acetylcholinesterase. The determination was performed in plasma obtained from a Molothrus bonariensis individual without anticholinesterase chemical exposure. 


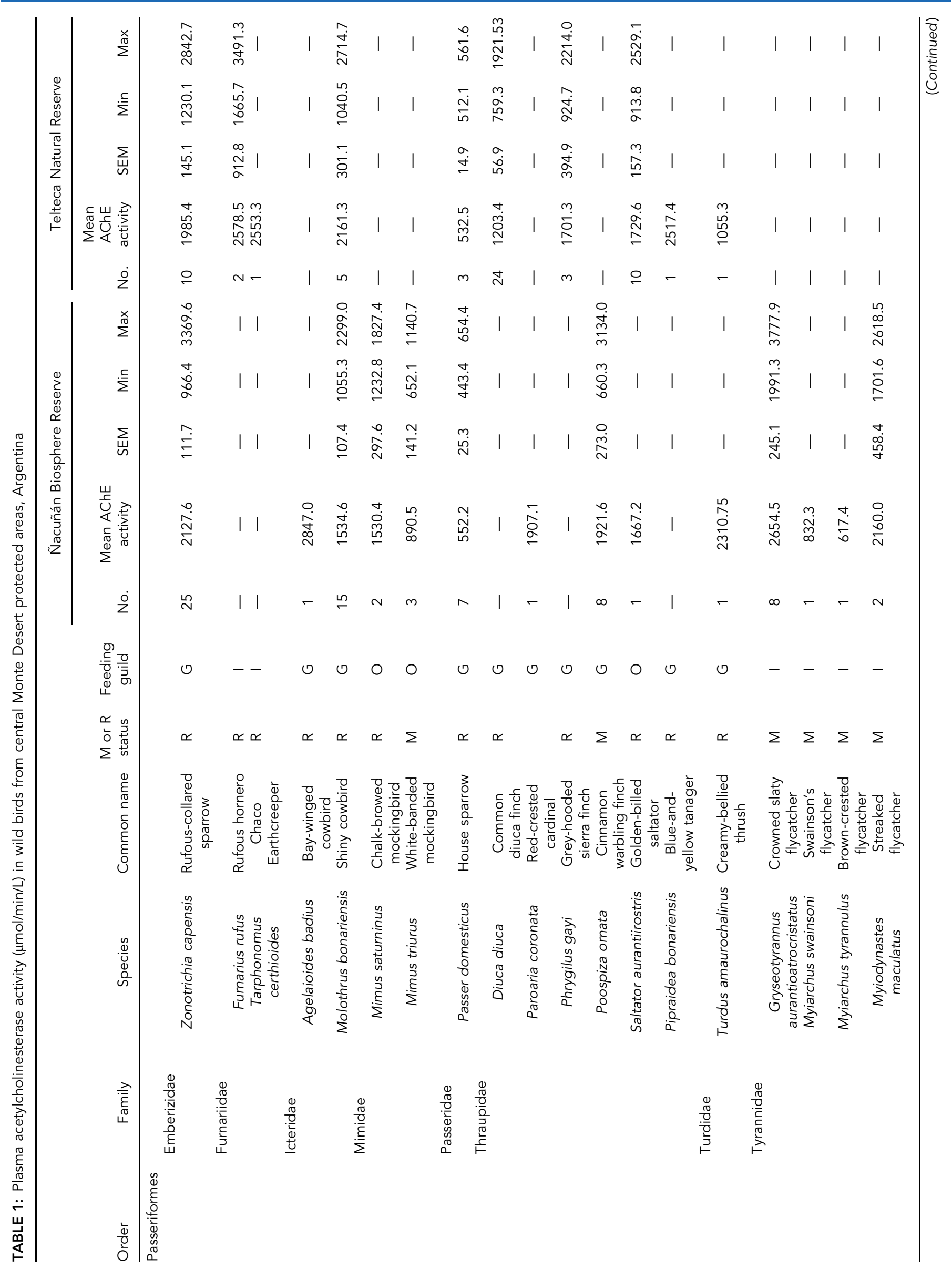




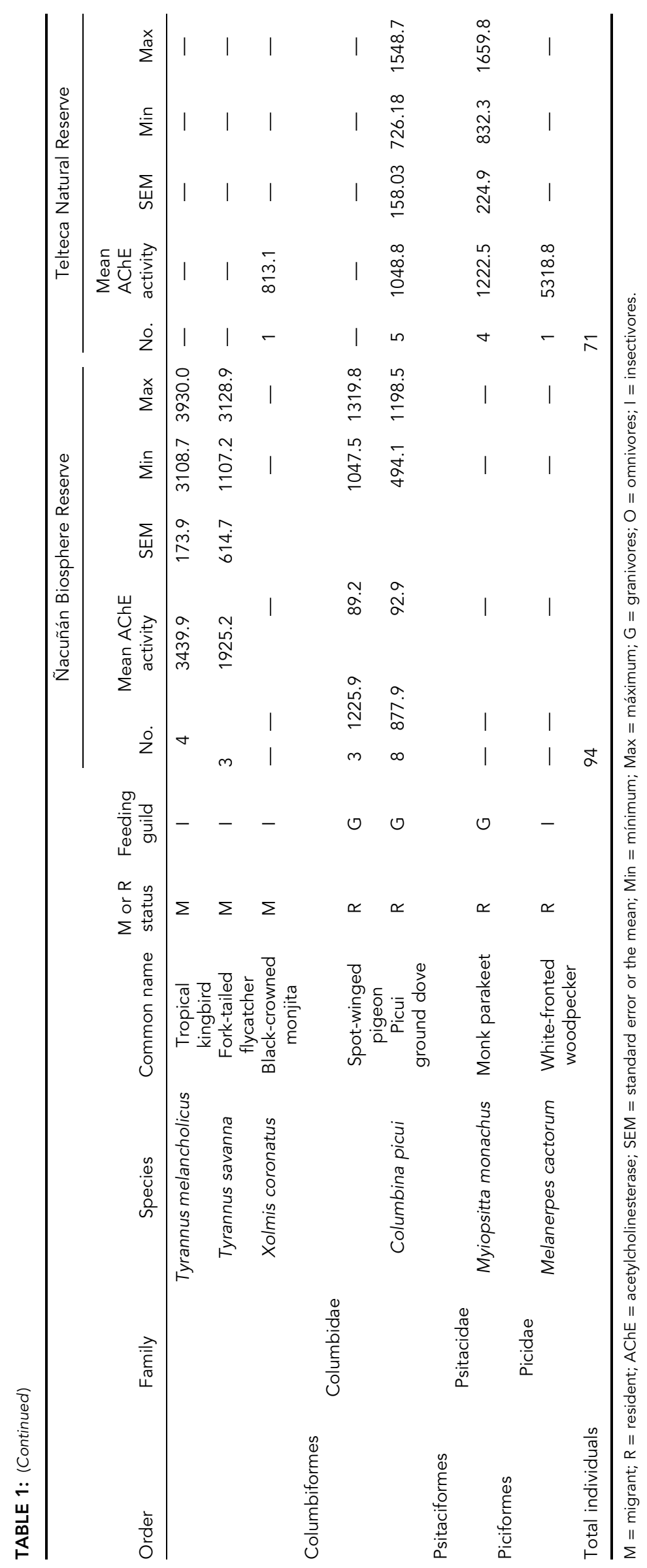


TABLE 2: Results of the generalized linear model showing variability in acetylcholinesterase activity among 8 species of wild birds from Monte Desert preservation areas

\begin{tabular}{|c|c|c|c|c|}
\hline Species $^{a}$ & Common name & $d f$ & $t$ Value & $p$ Value \\
\hline Zonotrichia capensis & Rufous-collared sparrow & 120.81663 & 8.727 & $1.73 \mathrm{e}-14^{*}$ \\
\hline Molothrus bonariensis & Shiny cowbird & 120.98604 & 5.728 & $7.56 \mathrm{e}-08^{\star}$ \\
\hline Passer domesticus & House sparrow & 120.43590 & -4.191 & 5.33 e- $05^{\star}$ \\
\hline Diuca diuca & Common diuca finch & 31.97476 & 2.610 & $0.0137^{\star}$ \\
\hline Poospiza ornata & Cinnamon warbling finch & 109.75228 & 5.263 & $7.10 \mathrm{e}-07^{*}$ \\
\hline Saltator aurantiirostris & Golden-billed saltator & 72.15671 & 5.178 & $1.95 \mathrm{e}-06^{*}$ \\
\hline Gryseotyrannus aurantioatrocristatus & Crowned slaty flycatcher & 109.75228 & 8.223 & $4.41 \mathrm{e}-13^{*}$ \\
\hline Columbina picui & Picui ground dove & 18.32000 & 84.694 & $<2$ e- $16^{\star}$ \\
\hline
\end{tabular}

${ }^{a}$ The interspecies differences were analyzed among those species in which 5 or more individuals were available.

${ }^{*} p<0.05$.

Safety Authority 2009). Therefore, knowledge of diets would be valuable for evaluation of possible exposure scenarios.

In conclusion, the substantive importance of our research lies in the fact that no enzymatic data have previously been available indicative of neurotoxicity for the bird species that inhabit the Monte Desert. In addition, in this same vast phytogeographic region, the same species also inhabit other areas where agricultural activities are carried out with neurotoxic pesticides. If in these areas we want to evaluate the effect of pesticide applications, we need reference values like those of the present study, ideally in the same species. Our study is of clinical importance for veterinarians who treat cases of intoxicated birds, and has scientific relevance because we have studied biochemical aspects not previously addressed in birds of this region. Plasma AchE enzymatic activity levels are proposed for the first time for 22 species of Passeriformes, 2 Columbiformes, 1 Psitaciformes, and 1 Piciforme that inhabit the central Monte Desert region. In the 8 species in which 5 or more individuals were obtained ( $Z$. capensis, M. bonariensis, P. domesticus, Diuca diuca, P. ornata, S. aurantiirostris,

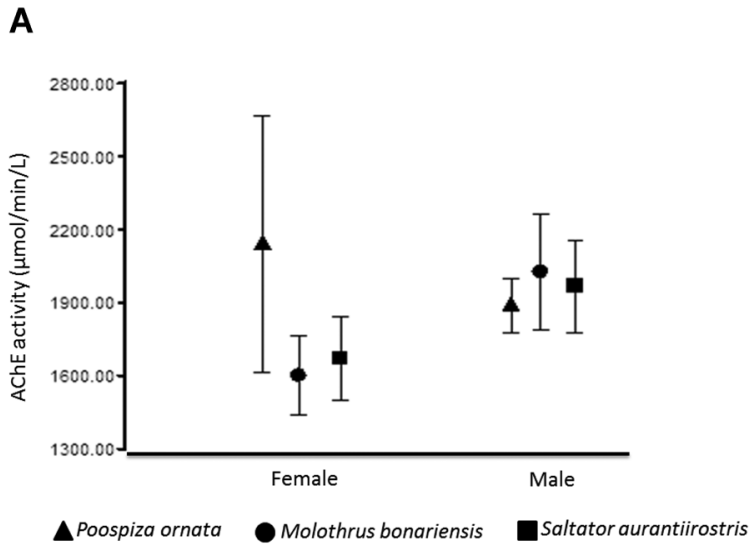

B

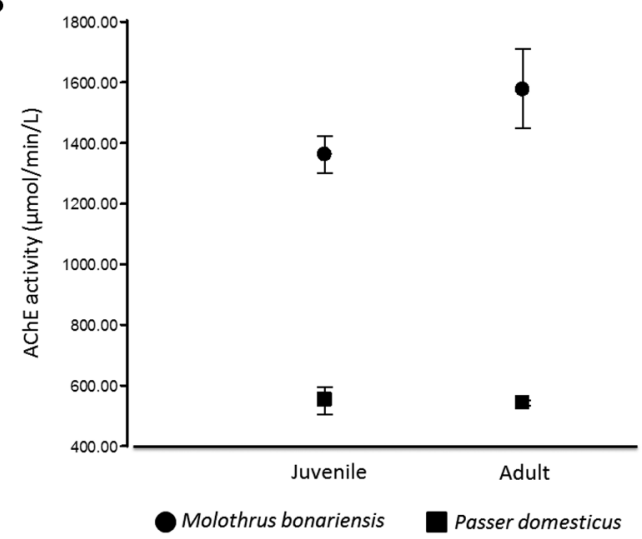

C

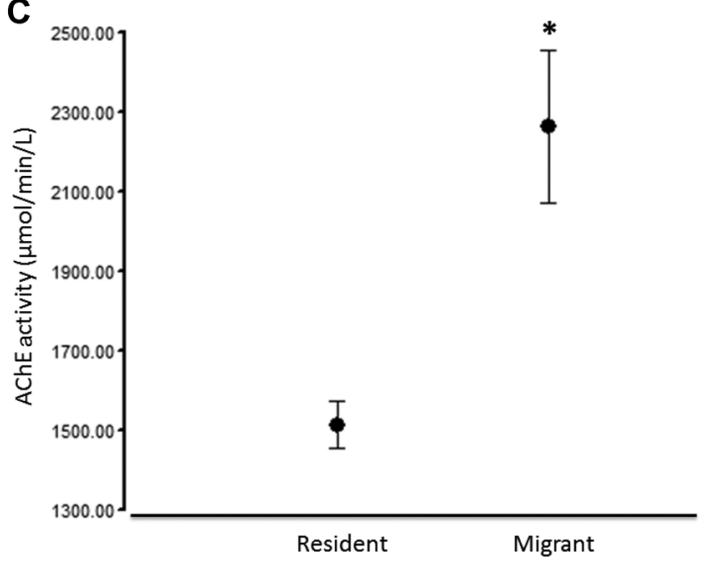

D

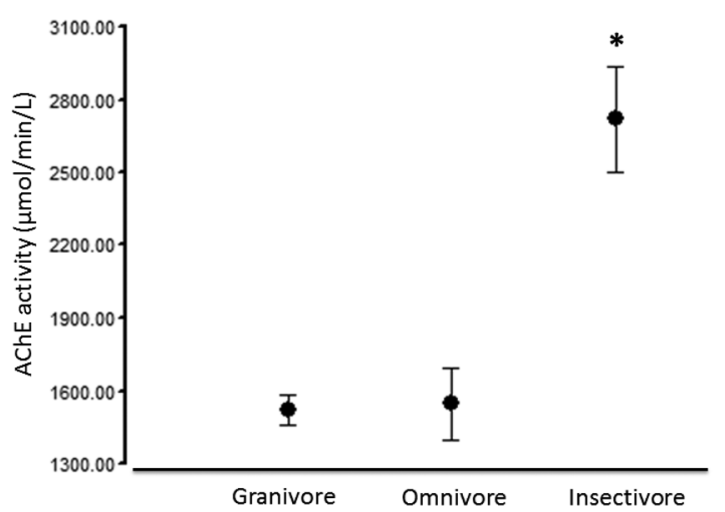

FIGURE 3: Analysis of plasma cholinesterase activity according to different factors in wild birds from the central Monte Desert. AChE = acetylcholinesterase. Data are \pm standard error. (A) Sex, Molothrus bonariensis: females $(n=6)$ and males $(n=11)$; Poospiza ornata: females $(n=4)$ and males $(n=4)$; Saltator aurantiirostris: females $(n=5)$ and males $(n=6)$. (B) Age, M. bonariensis: juvenile $(n=3)$ and adult $(n=12)$; Passer domesticus: juvenile $(n=4)$ and adult $(n=6)$. (C) Residence status, resident $(n=123)$ and migrant $(n=26) .{ }^{*} p<0.001$. (D) Feeding habits in granivores $(n=117)$, insectivores $(n=18)$, and omnivores $(n=14) .{ }^{*} p<0.001$. 
Gryseotyrannus aurantioatrocristatus, and C. picui, interspecific differences in AChE levels are demonstrated. These can be considered pre-exposure levels for future comparative studies with disturbed areas.

Supplemental Data-The Supplemental Data are available on the Wiley Online Library at DOI: 10.1002/etc.4458.

Acknowledgment-The authors thank S. Mendez, K. Jaurie, D. Ordovini, and Y. Olivi for actively collaborating in field campaigns, and the forest rangers of the both Nature Reserves. The present study was made possible by the financial support of the Juan Agustín Maza University UMAZA (Res. N 340/17 Mendoza, Argentina) and the doctoral fellowship from National Council of Scientific and Technical Research (Buenos Aires, Argentina). The samplings were made with prior authorization from the Secretariat of Fauna of the Directorate of Renewable Natural Resources of the Province of Mendoza (resolution 1274).

Data Accessibility-Data, associated metadata, and calculation tools are available from the corresponding author (https://noragorla@gmail.com and https://aamartinquero@ gmail.com).

\section{REFERENCES}

Abraham E, Del Valle HF, Roig F, Torres L, Ares JO, Coronato F, Godagnone R. 2009. Overview of the geography of the Monte Desert biome (Argentina). J Arid Environ 73:144-153.

Anderson TR. 2006. Biology of the Ubiquitous House Sparrow: From Genes to Populations. Oxford University, New York, NY, USA.

BirdLife International. 2018. Important Bird and Biodiversity Areas (IBAs). [cited 2018 December 2]. Available from: http://datazone.birdlife. org/home

Cobos VM, Mora MA, Escalona G, Calme S, Jiménez Cobos J. 2010. Variation in plasma cholinesterase activity in the clay-colored robin (Turdus grayi) in relation to time of day, season, and diazinon exposure. Ecotoxicology 19:267-272.

Cueto VR, Casenave JL, Marone L. 2008. Neotropical austral migrant landbirds: Population trends and habitat use in the central Monte Desert, Argentina. Condor 110:70-79.

Ellman GL, Courtney KD, Andres V, Featherstone RM. 1961. A new and rapid colorimetric determination of acetylcholinesterase activity. Biochem Pharmacol 7:88-95.

European Food Safety Authority. 2009. Risk assessment for birds and mammals: GD risk assessment for birds \& mammals. EFSA J 7:1438.

Fair JM, Jones J, eds. 2010. Guidelines to Use Wild Birds in Research. The Ornithological Council, Council Bluffs, IA, USA.

Ferré D, Saldeña E, Albarracín L, Neuilly V, Gorla N. 2015. Inhibición de butirilcolinesterasa en dos perros intoxicados y confirmación analítica de carbofuran como agente causal. Rev Vet 26:43-48.

Ferré DM, Quero AAM, Hernández AF, Hynes V, Tornello MJ, Lüders C, Gorla NBM. 2018. Potential risks of dietary exposure to chlorpyrifos and cypermethrin from their use in fruit/vegetable crops and beef cattle productions. Environ Monit Assess 190:292.

González-Escalante L, Mercado-Hernández R, González-Rojas Jl, Bermúdez, deLeón M. 2013. Plasma cholinesterase activity in the house finch, Carpodacus mexicanus, and the house sparrow, Passer domesticus, collected from pesticide-exposed agricultural land. Bull Environ ContamToxicol 90:9-11.

Guitart R, Croubels S, Caloni F, Sachana M, Davanzo F, Vandenbroucke V, Berny P. 2010. Animal poisoning in Europe. Part 1: Farm livestock and poultry. Vet J 183:249-254.
Horowitz IH, Yanco EG, Landau S, Nadler-Valency R, Anglister N, BuellerRosenzweig A, Apelbom-Halbersberg T, Cuneah O, Hanji V, Bellaiche M. 2016. Whole blood cholinesterase activity in 20 species of wild birds. $J$ Avian Med Surg 30:122-126.

Kaneko JW, Bruss ML, Harvey JJ. 2008. Clinical Biochemistry of Domestic Animals, 6th ed. Elsevier, Oxford, UK.

Kuznetsova A, Brockho PB, Christensen RHB. 2017. ImerTest Package: Tests in linear mixed effects models. J. Stat Softw 82:1-26.

Maul JD, Farris JL. 2004. Monitoring exposure of passerines to acephate, dicrotophos, and malathion using cholinesterase reactivation. Bull Environ Contam Toxicol 73:682-689.

Miao Y, He N, Zhu JJ. 2010. History and new developments of assays for cholinesterase activity and inhibition. Chem Rev 110: 5216-5234.

Mineau P. 2002. Estimating the probability of bird mortality from pesticide sprays on the basis of the field study record. Environ Toxicol Chem 21:1497-1506.

Mitra A, Chatterjee C, Mandal FB. 2011. Synthetic chemical pesticides and their effects on birds. Res J Environ Toxicol 5:81-96.

Norte AC, Sheldon BC, Sousa JP, Jaime A, Ramos JA. 2009. Environmental and genetic variation in body condition and blood profile of great tit Parus major nestlings. J Avian Biol 40:157-165.

Nunes B. 2011. The use of cholinesterases in ecotoxicology. In Whitacre DM, ed, Reviews of Environmental Contamination and Toxicology. Vol 212. Springer, New York, NY, USA, pp 29-59.

Oropesa AL, Gravato C, Sánchez S, Soler F. 2013. Characterization of plasma cholinesterase from the white stork (Ciconia ciconia) and its in vitro inhibition by anticholinesterase pesticides. Ecotoxicol Environ Saf 97:131-138.

Ralph CJ, Geupel GR, Pyle P, Martin TE, DeSante DF, Milá B. 1996. Manual de Métodos de Campo para el Monitoreo de Aves Terrestres. Pacific Southwest Research Station, Albany, CA, USA.

Remsen JV, Areta JJ, Cadena CD, Jaramillo A, Nores M, Pacheco J, Pérez-Emín J, Robbins MB, Stiles FG, Stotz DF, Zimmer KJ. 2015. A classification of the bird species of South America. American Ornithologists Union, Chicago, IL, USA. [cited 2018 November 7]. Available from. http://www.museum.Isu.edu/ Remsen/SACCBaseline.html

Roy C. 2005. Plasma B-esterase activities in European raptors. J Wildlife Dis 41:184-208.

Ruvalcaba-Ortega I, Bermúdez de León M, Mendiola-Castillo S, GonzálezEscalante L, Canales-del-Castillo R, Mercado-Hernández R, Guzmán-Velasco A, González-Rojas JI. 2017. Evaluation of plasma cholinesterase activity in native birds from pesticide-exposed agricultural lands. Range Ecol Manag 70:584-588.

Saldeña EL, Hynes V, Ferré DM, Quero AÁM, Neuilly V, Gorla NBM. 2017. Evento de intoxicación en perros de zona urbana mediante cebos contaminados con aldicarb. Rev Invest Vet Perú 28:514-521.

Sánchez-Barbudo IS, Camarero P, Mateo R. 2012. Intoxicaciones intencionadas y accidentales de fauna silvestre y doméstica en España: Diferencias entre Comunidades Autónomas. Rev Toxicol 29:20-28.

Shimshoni J, Evgeny E, Lublin A, Cuneah O, King R, Horowitz I, Shlosberg A. 2012. Determination of brain cholinesterase activity in normal and pesticide exposed wild birds in Israel. Israel. J Vet Med 67:214-219.

Smith AD, McWilliams SR. 2014. What to do when stopping over: Behavioral decisions of a migrating songbird during stopover are dictated by initial change in their body condition and mediated by key environmental conditions. Behav Ecol 25:1423-1435.

Strum KM, Hooper MJ, Johnson KA, Lanctot RB, Zaccagnini ME, Sandercock BK. 2010. Exposure of nonbreeding migratory shorebirds to cholinesterase-inhibiting contaminants in the Western Hemisphere. Condor 112:15-28.

Stuber MJ, Hooper MJ, Belthoff JR. 2018. Examination of pesticide exposure in burrowing owls nesting in agricultural and nonagricultural areas in the Morley Nelson Snake River Birds of Prey National Conservation Area, Idaho. J Raptor Res 52:191-206.

Tecles F, Cerón JJ. 2001. Determination of whole blood cholinesterase in different animal species using specific substrates. Res Vet Sci 70:233-238.

Toxicological Information Center. 2018. Centro Información Toxicológica Departamento Toxicología. Mendoza, Argentina. [cited 2018 December 10]. Available from: http://www.salud.mendoza.gov.ar/contactos/ toxicologia/ 
Trudeau SF, Sans Cartier GL. 2000. Biochemical methods to determine cholinesterase activity in wildlife exposed to pesticides, Technical report series. Canadian Wildlife Service, Minister of Public Works and Government Services, Ottawa, ON, Canada.

Vaughan-Higgins R, Vitali S, Reiss A, Besier S, Hollingsworth T, Smith G. 2016. Development of reference ranges for plasma total cholinesterase and brain acetylcholinesterase activity in free-ranging carnaby's black-cockatoos (Calyptorhynchus latirostris). J Wildlife Dis 52:592-598.
Villagra PE, Defosse GE, del Valle HF, Tabeni S, Rostagno M, Cesca E, Abraham E. 2009. Land use and disturbance effects on the dynamics of natural ecosystems of the Monte Desert: Implications for their management. J Arid Environ 73:202-211.

Zwarg T, Prioste F, Thijl Vanstreels RE, Dos Santos RJ, Matushima ER. 2012. Normal plasma cholinesterase activity of neotropical falconiformes and strigiformes. J Raptor Res 46:201-207. 